\title{
DISTRIBUTION OF AFLATOXINS IN CONTAMINATED CORN FRACTIONS SEGREGATED BY SIZE
}

\author{
Fabiana S. Piedade ${ }^{1}$; Homero Fonseca ${ }^{2 *}$; Eduardo M. Glória³; Maria Antonia Calori-Domingues ${ }^{3}$; \\ Sônia M.S. Piedade ${ }^{4}$; Décio Barbin ${ }^{4}$
}
'Escola Superior de Agricultura “Luiz de Queiroz”, Universidade de São Paulo, Piracicaba, SP, Brasil; ${ }^{2}$ Departamento da Produção Vegetal, ${ }^{3}$ Departamento de Agroindústria, Alimentos e Nutrição, ${ }^{4}$ Departamento de Ciências Exatas, Escola Superior de Agricultura “Luiz de Queiroz” Universidade de São Paulo, Piracicaba, SP, Brasil

Submitted: October 06, 2000; Returned to authors for corrections: May 07, 2001; Approved: February 25, 2002

\begin{abstract}
The efficiency of segregation, by particle size, in reducing the aflatoxin content of corn lots under the Brazilian conditions was studied. The aflatoxin content, in the corn fractions obtained after sieving thirty contaminated samples, with approximately $3.0 \mathrm{~kg}$ each, was determined. The samples were passed through 4.5 $\mathrm{mm}$ round-hole sieves and the fractions with particles ${ }^{3} 4.5 \mathrm{~mm}$ (fraction A) and $<4.5 \mathrm{~mm}$ (fraction $\mathrm{B}$ ) and then analyzed for aflatoxins by TLC. The results showed that the distribution of the aflatoxins among the fractions A and B varied from sample to sample. However, the fraction B presented higher content ( 6 to $1,422 \mu \mathrm{g} / \mathrm{kg}$ ) of aflatoxins ( $\mathrm{P}<5 \%$ ), than samples of fraction A (4 to $389 \mu \mathrm{g} / \mathrm{kg}$ ). In spite of that the segregation of this fraction did not reduce significantly the contamination of the samples. This probably occurred because the contribution of the fraction $B$ for the estimated total of the concentration of aflatoxin of the sample was smaller than that of the fraction A, due to the smallest amount of the fraction B in the sample weight total. In spite of being significant for the studied samples the correlation among the percentages of the groups of grains with defects a) burning grains, sprouted, burned and moldy and b) total injured, with the estimated level of contamination for the samples, more studies will be necessary so that better conclusions can be drawn for this correlation.
\end{abstract}

Key words: aflatoxin, corn, contamination distribution, segregation, fractions

\section{INTRODUCTION}

Corn is a cereal worldwide utilized for human consumption and animal feeding. In Brazil it is the most important grain representing ca. $40 \%$ of all grains produced in the last five years (1). Corn is susceptible to fungi development and aflatoxin contamination that can occur in any phase of its production (2). Several studies made in this country such as the surveys of Fonseca et al. $(7,8)$, Glória et al. (9) and others $(12,13,18)$ have shown the contamination of corn with aflatoxins.

Aflatoxins are harmful to man and animals with biological and biochemical effects. They are considered carcinogenic, teratogenic and mutagenic substances and can affect the metabolism of carbohydrates, lipids, proteins and nucleic acids (6).
In Brazil, the maximum level of aflatoxins allowed in corn is 20 $\mu \mathrm{g} / \mathrm{kg}$ (3). The contamination of agricultural products with mycotoxins usually occurs in a non-uniform way, and a few highly contaminated kernels are distributed among many noncontaminated ones. This fact is the cause of the great variation in the mycotoxins concentration in samples of a lot, turning difficult the determination of the real concentration of the toxins (20).

Johnson et al. (10) studied the distribution of aflatoxin in contaminated lots and the results suggested that the toxin was present mostly in the fractions of impurities and other materials and that the removal of this material would contribute to reduce of the initial content of aflatoxin.

Brekke et al. (5) tested the efficiency of some processes of physical segregation trying to decrease the contamination of

* Corresponding author. Mailing address: Rua Dona Eugênia, 269 - 13416-218 - Piracicaba, SP, Brasil. 
corn lots with aflatoxins and concluded that the segregation of the fractions, classified as residue, did not reduce significantly the initial levels.

Shotwell et al. $(15,16)$ observed in visually segregated fractions and broken corn kernels and foreign material $(<4.8$ $\mathrm{mm}$ ) that the aflatoxin distribution varied for each studied lot and that the segregation of the fraction constituted by broken kernels and foreign material was not sufficient to eliminate aflatoxin from the lots.

Meinders and Hurburg (11) studied the characteristics of the fractions (sizes between 1.8 and $6.3 \mathrm{~mm}$ ) of 39 samples of corn pre-cleaning residues from many parts of the USA, and found only one sample contaminated with aflatoxin but 36 samples were contaminated with fumonisin in one or all fractions. They also observed a rise in aflatoxins levels as the particle size of the segregated material was decreased from 6.3 to $1.8 \mathrm{~mm}$.

Corn lots are usually subjected to a pre-cleaning segregation by particle size aiming to eliminate undesirable broken kernels and foreign material before storage and commercialization (19). In Brazil this operation is usually made by sieving the material through $4.5 \mathrm{~mm}$ round-holes sieves. However, there is no data on the aflatoxin distribution in the fractions obtained this way.

The present work aimed to verify the efficiency of segregation, by particle size, in reducing the aflatoxin contamination of corn.

\section{MATERIALS AND METHODS}

Thirty samples of aflatoxin-contaminated corn were taken from truckloads as they arrived to a corn processing plant in the State of São Paulo, Brazil.

Two samplings were made in two different periods and 16 samples (in the first) and 14 (in the second) were taken. Each sample was composed of several incremental samples taken from different points of the load, according to the industry's own scheme, and mixed to form bulk samples that varied from 2.4 to $3.9 \mathrm{~kg}$.

Every sample was analyzed for aflatoxin in the industry, using the screening technique of the bright greenish-yellow fluorescence (BGYF). If positive, the samples were tested by an immunoaffinity column method (Aflatest) for confirmation.

The samples were classified in types (Table 1), at the reception in the processing plant, according to the Brazilian rules for corn classification (4), as described bellow:

Fermented, heated and sprouted grains - discolored grains or pieces of grains, due to the action of heat and humidity or fermentation in more than $1 / 4$ of the size of the grain, and grains or pieces of grains with visible germination.

Injured grains - grains or pieces of grains, hollow, immature, attacked by insects, rodents or parasites or those fermented up to $1 / 4$ of the grain size, as well as injured by different causes.

Impurities, foreign materials and broken grains - either fragments of the corn plant, including grains or fragments of
Table 1. Levels of tolerance for corn grading, by types, according to Brazilian rules (Brazil, 1976).

\begin{tabular}{|c|c|c|c|c|}
\hline \multirow{3}{*}{ Type } & \multicolumn{4}{|c|}{$\begin{array}{c}\text { Tolerance } \\
\text { (Weight percentage) }\end{array}$} \\
\hline & \multirow[b]{2}{*}{ Moisture } & \multirow[b]{2}{*}{$\begin{array}{c}\text { Foreign materials, } \\
\text { impurities and } \\
\text { broken }\end{array}$} & \multicolumn{2}{|r|}{ Damaged } \\
\hline & & & Total & $\begin{array}{c}\text { Maximum of } \\
\text { fermented, } \\
\text { sprouted and heated }\end{array}$ \\
\hline 1 & $14.5 \%$ & $1.5 \%$ & $11 \%$ & $3 \%$ \\
\hline 2 & $14.5 \%$ & $2.0 \%$ & $18 \%$ & $6 \%$ \\
\hline 3 & $14.5 \%$ & $3.0 \%$ & $27 \%$ & - \\
\hline B.S. ${ }^{a}$ & $14.5 \%$ & (To be specif & ied in & each situation) \\
\hline
\end{tabular}

${ }^{\mathrm{a}}$ B.S. = Below Standard.

grains capable to pass through a sieve with $5 \mathrm{~mm}$ diameter orifices, and grains or seeds of other species, as well as the vegetal remainings and strange bodies of any nature, not originated from the product.

After grading the samples were sent to the laboratory and stored in the freezer at the $-18^{\circ} \mathrm{C}$, until further processing and analysis.

Each sample was passed through a $4.5 \mathrm{~mm}$ round-holes sieve, resulting in two fractions: A) the fraction that was retained in the sieve, i.e. larger or equal to $4.5 \mathrm{~mm}$ particles, and $\mathbf{B}$ ) the fraction that passed through the sieve (particles or kernels smaller than $4.5 \mathrm{~mm}$ ). The $\mathbf{A}$ fraction was divided into two portions of approximately equal weight by a Gamet type sub sampler. Only one of these portions was utilized in this study.

The fraction $\mathbf{A}$ of each sample was weighed and if the amount of material was over $0.5 \mathrm{~kg}$ it was subsampled and coarsely ground in the Romer Analytical Subsampling mill. The obtained subsample was later ground in a hammer mill to pass a 20-mesh sieve. A $50 \mathrm{~g}$ analytical sample was taken from each subsample, and analyzed for aflatoxin in duplicate.

The fraction $\mathbf{B}$ of each sample was weighed and if less than $0.5 \mathrm{~kg}$, the whole fraction was ground in a hammer mill to pass a 20-mesh sieve. A $15 \mathrm{~g}$ analytical sample was then taken for aflatoxin analysis. Each fraction was analyzed in duplicate but, in the case of insufficient material, just one analytical sample was analyzed.

A variation of $30 \%$ in the results in the duplicate analyses of the fractions was accepted. Above this limit the analyses were repeated. To express the contamination levels, the mean values of the duplicates were utilized.

Aflatoxins $B_{1}, B_{2}, G_{1}$ and $G_{2}$, were extracted according to Soares and Rodriguez-Amaya (17) and detection was made by two-dimensional development in $10 \mathrm{~cm}$ TLC plates. The detection limit was of $1 \mathrm{ng} / \mathrm{g}$ for all aflatoxins. For aflatoxin identity confirmation the chemical derivatization procedure of AOAC - 985.17 was utilized (14). 


\section{RESULTS AND DISCUSSION}

Analyzing the qualitative characteristics of the samples and its classification for types (Table 1) according to the Brazilian official regulations (4) and shown in the Table 2, it can be seen that there was a predominance of types 3 and Bellow Standard - B.S. (10 and 13 samples, respectively). Types 1 and 2 occurred in a smaller proportion ( 3 and 4 samples, respectively). In spite of the reduced number of data, these might indicate a higher probability of finding samples of types 3 or BS contaminated with aflatoxins. However, the proportions of types of defects: a) fermented, heated and sprouted grains, b) injured grains and c) the impurities/strange materials, found in the samples show a correlation index with the estimated levels of contamination for sample of $\mathbf{r}=0.50,0.62$ and 0.25 ,

Table 2. Physical properties and classification, by types, (Brazilian rules) of the corn samples.

\begin{tabular}{|c|c|c|c|c|c|}
\hline Sample & $\begin{array}{l}\text { Moisture } \\
\text { content } \%\end{array}$ & $\begin{array}{c}\text { Injured } \\
\%\end{array}$ & $\begin{array}{c}\text { Fermented } \\
\%\end{array}$ & $\begin{array}{c}\text { Impurities } \\
\%\end{array}$ & $\begin{array}{c}\text { Classification } \\
\text { by types }\end{array}$ \\
\hline 1 & 13.70 & 6.40 & 3.10 & 1.50 & 2 \\
\hline 2 & 11.10 & 7.00 & 2.40 & 3.30 & BS \\
\hline 3 & 13.70 & 8.20 & 3.1 & 2.40 & 3 \\
\hline 4 & 13.40 & 9.50 & 3.40 & 3.00 & 3 \\
\hline 5 & 13.90 & 5.00 & 3.30 & 1.40 & 2 \\
\hline 6 & 12.70 & 9.50 & 6.60 & 3.20 & BS \\
\hline 7 & 13.30 & 7.90 & 2.80 & 3.10 & BS \\
\hline 8 & 12.20 & 7.90 & 3.60 & 4.00 & BS \\
\hline 9 & 14.90 & 11.60 & 3.40 & 3.10 & BS \\
\hline 10 & 12.40 & 8.20 & 2.60 & 1.90 & 2 \\
\hline 11 & 12.60 & 10.00 & 1.90 & 1.50 & 1 \\
\hline 12 & 13.20 & 7.40 & 4.00 & 2.50 & 3 \\
\hline 13 & 13.20 & 10.30 & 3.10 & 3.40 & BS \\
\hline 14 & 13.80 & 8.20 & 3.10 & 3.00 & 3 \\
\hline 15 & 13.40 & 6.80 & 2.30 & 1.30 & 1 \\
\hline 16 & 13.40 & 10.40 & 2.40 & 2.80 & 3 \\
\hline 17 & 13.10 & 6.10 & 2.10 & 3.70 & BS \\
\hline 18 & 12.00 & 11.90 & 3.90 & 3.30 & BS \\
\hline 19 & 12.20 & 11.70 & 3.20 & 4.40 & BS \\
\hline 20 & 11.80 & 7.40 & 1.40 & 2.00 & 2 \\
\hline 21 & 12.80 & 10.00 & 2.20 & 3.50 & $\mathrm{BS}$ \\
\hline 22 & 11.70 & 9.20 & 1.00 & 1.30 & 1 \\
\hline 23 & 12.90 & 10.60 & 2.00 & 3.40 & BS \\
\hline 24 & 12.70 & 10.40 & 1.30 & 2.70 & 3 \\
\hline 25 & 12.40 & 20.40 & 4.40 & 3.10 & BS \\
\hline 26 & 12.80 & 9.90 & 0.80 & 2.40 & 3 \\
\hline 27 & 13.60 & 7.20 & 3.90 & 2.70 & 3 \\
\hline 28 & 12.70 & 10.60 & 0.70 & 3.90 & BS \\
\hline 29 & 12.70 & 11.20 & 2.70 & 2.70 & 3 \\
\hline 30 & 12.40 & 17.10 & 7.20 & 2.60 & 3 \\
\hline
\end{tabular}

a - Classification of corn in types 1, 2, 3 and BS according to the percentage of defects observed in the lots.
Table 3. Mean values of aflatoxins $B_{1}+B_{2}+G_{1}+G_{2}$, in $\mu \mathrm{g} / \mathrm{kg}$, in the studied fractions, fraction weight and contribution of fraction to total sample level of contamination.

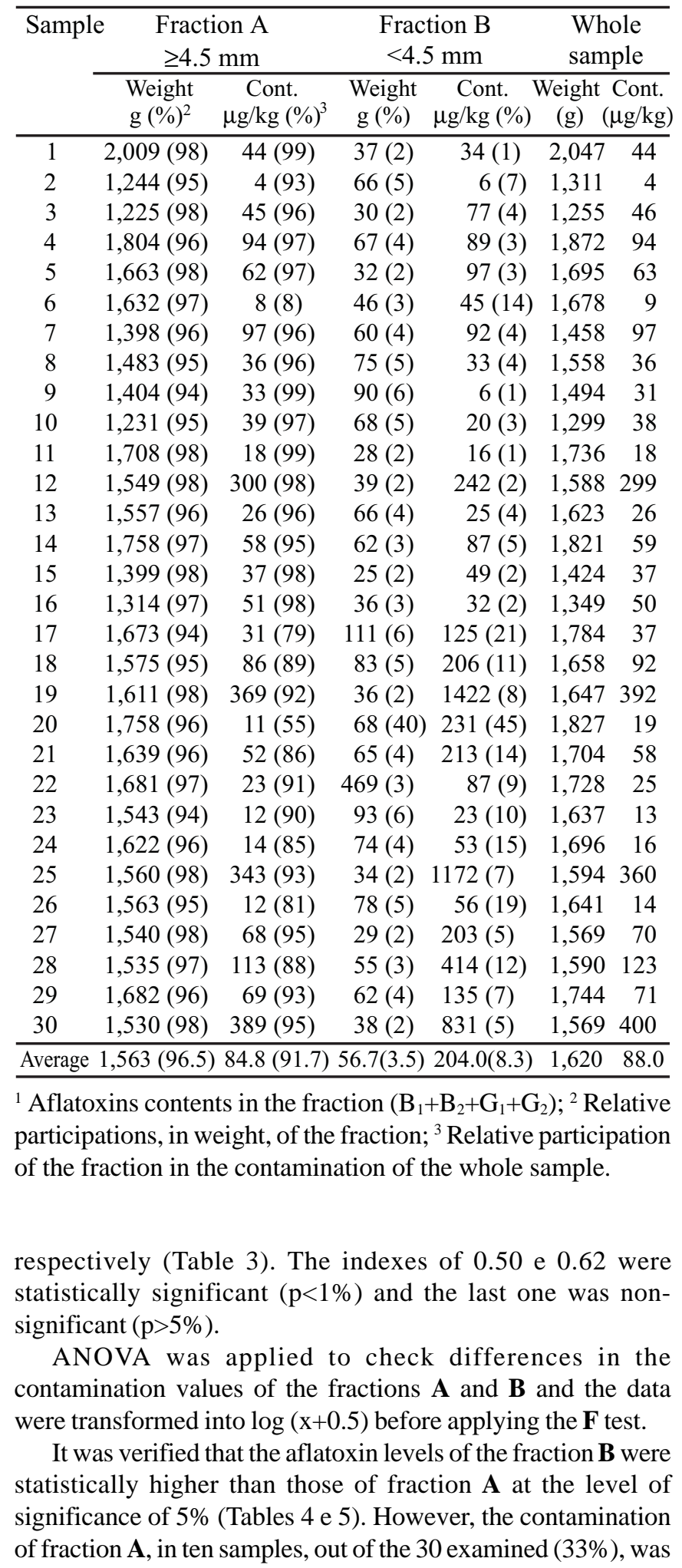


Table 4. Analysis of variance.

\begin{tabular}{crrcrr}
\hline $\begin{array}{c}\text { Variation } \\
\text { factor }\end{array}$ & G.L. & S.Q. & Q.M. & F Value & Prob.>F \\
\hline Fraction & 1 & 6.7501433 & 6.7501433 & 4.8349 & 0.02999 \\
Residue & 58 & 80.9746390 & 1.3961145 & & \\
Total & 59 & 87.7247823 & & & \\
\hline
\end{tabular}

Overall mean $=4.171977 ;$ Coefficient of variation $=28.322 \%$.

Table 5. Mean values of the factor fraction.

\begin{tabular}{ccccc}
\hline Treat. No. & Name & Repet. No. & Averages & $\begin{array}{c}\text { Original } \\
\text { averages }\end{array}$ \\
\hline 1 & FA $^{\mathrm{a}}$ & 30 & $4.507391 \mathbf{a}$ & 90.184870 \\
2 & $\mathrm{FB}^{\mathrm{b}}$ & 30 & $3.836563 \mathbf{b}$ & 45.865842 \\
\hline
\end{tabular}

$\mathbf{a}-\mathrm{FA}=$ Fraction $34.5 \mathrm{~mm} ; \mathbf{b}-\mathrm{FB}=$ Fraction $<4.5 \mathrm{~mm}$.

higher than that of the fraction $\mathbf{B}$ (Table 3 ). This suggests a variation from lot to lot in the behavior of the contamination levels between the fractions.

On the other hand, Table 3 shows that the average proportion of the fraction $\mathbf{A}$, in the total weight of the samples, was $96.5 \%$ against $3.5 \%$ of the fraction $\mathbf{B}$. Even though the fraction $\mathrm{A}$ had a lower average of aflatoxin content $(84.8 \mathrm{ng} / \mathrm{kg}$ against 204.0 $\mu \mathrm{g} / \mathrm{kg}$ of the fraction $\mathbf{B}$ ) the influence of the fraction $\mathbf{A}$ was very high due to its major weight in samples.

Such data suggests that the segregation of the proportionally smaller fraction, containing the higher levels of the toxin, would not decrease the level of contamination of the lots. These results agree with the ones found by Shotwell et al. (15) and Brekke et al. (5).

\section{CONCLUSIONS}

The aflatoxin distribution between fractions containing particles with sizes smaller or greater than $4.5 \mathrm{~mm}$, can vary from sample to sample of corn. Nevertheless, the fraction with particles $<4.5 \mathrm{~mm}$ has presented higher contents of aflatoxin, showing that the use of this material must be of great concern. Due to the small participation of the fraction with particles smaller than $4.5 \mathrm{~mm}$, it would not significantly increase the overall contamination of the sample. The segregation of this fraction from the original sample did not significantly diminish the contamination of the sample.

The correlation significance among the percentage of defects measured by the Brazilian classification rules for corn did not correlated with the aflatoxin contents of the sample even though a high number of samples of grade 3 and BS were found. More studies are need with a higher number of samples to achieve more consistent correlations and conclusions

\section{RESUMO}

\section{Distribuição da aflatoxina em frações de milho contaminado, segregadas por tamanho}

Este trabalho teve como objetivo estudar o conteúdo de aflatoxina em frações granulométricas de milho obtidas após peneiragem de trinta amostras, de 3,0 kg cada, sabidamente contaminadas com aflatoxinas. As amostras foram passadas por peneiras com crivos redondos de 4,5 mm obtendo-se as frações com partículas 3 4,5 mm (fração $\mathbf{A}$ ) e $<4,5 \mathrm{~mm}$ (fração $\mathbf{B}$ ), que foram analisadas para presença de aflatoxinas através da cromatografia de camada delgada. Os resultados mostraram que a distribuição da concentração de aflatoxinas entre as frações granulométricas A e B variou de amostra para amostra de milho. Contudo, a fração B apresentou maior conteúdo (6 a $1.422 \mu \mathrm{g} / \mathrm{kg}$ ) de aflatoxina ( $\mathrm{P}<5 \%$ ) a fração A (4 a $389 \mu \mathrm{g} / \mathrm{kg})$. Apesar disso, a segregação desta fração não diminuiu significativamente a contaminação da amostra. Isto ocorreu provavelmente porque a contribuição da fração $\mathbf{B}$ para o total estimado da concentração de aflatoxina da amostra foi menor que o da fração $\mathbf{A}$, devido à menor quantidade da fração B no peso da amostra total. Apesar de ser significativa para as amostras estudadas, a correlação entre as percentagens dos grupos de grãos com defeitos, a) grãos ardidos, brotados, queimados e mofados e b) avariados totais, com o nível de contaminação estimado para as amostras, mais estudos serão necessários para que conclusões mais consistentes possam ser tiradas desta correlação.

Palavras-chave: aflatoxina, milho, distribuição da contaminação, segregação, frações

\section{REFERENCES}

1. Agrianual - FNP Consultoria e Comércio - Anuário Estatístico da Agricultura Brasileira. São Paulo, 1999.

2. Bradburn, N.; Blunden, G.; Coker, R.D.; Jewers, K. Aflatoxin contamination of maize. Trop. Sci., 33: 418-28, 1993.

3. Brasil. Leis, decretos, etc. Ministério da Agricultura. Portaria n 183, de 21 de março de 1996. Diário Oficial da União, Brasília, 25 de março de 1996.

4. Brasil. Leis, decretos, etc. Ministério da Agricultura. Portaria n 845 , de 08 de novembro de 1976. Diário Oficial da União, Brasília, 19 de novembro de 1976.

5. Brekke, O.L.; Peplinski, A.J.; Griffin Jr., E.L. Cleaning trials for corn containing aflatoxin. Cereal Chem., 52: 198-204, 1975.

6. Ellis, W.O.; Smith, J.P.; Simpson, B.K.; Oldham, J.H. Aflatoxins in Food: Occurrence, Biosynthesis, Effects on Organisms, Detection, and Methods of Control. Crit. Rev. Food Sci. Nutr., 30: 403-439, 1991.

7. Fonseca, H.; Nogueira, J.N.; Graner, M.; Oliveira, A.J.; Caruso, J.G.; Boralli, C.; Calori, M.A.; Khatounian, C.A. Natural occurrence of mycotoxins in some Brazilian foods. Part I. V International IUPAC Symposium on Mycotoxins and Phycotoxins, Vienna, Technical University, Austria. Proceedings, 1982, p.76-79.

8. Fonseca, H.; Nogueira, J.N.; Graner, M.; Oliveira, A.J.; Caruso, J.G.; Boralli, C.; Calori, M.A.; Khatounian, C.A. Natural occurrence of mycotoxins in some Brazilian foods. Part II. World Congress of Food Science and Technology, Dublin, 1983, p.53-4. 
9. Glória, E.M.; Fonseca, H.; Souza, I.M. Occurrence of mycotoxins in maize delivered to the food industry in Brasil. Trop. Sci., 37: 107$110,1997$.

10. Johnson, R.M.; Greenaway, W.T.; Dolan, W.P. Estimation of aflatoxin in corn by "dockage" assay. Journal of Association of the Official Analytical Chemists, 52: 1304-1306, 1969.

11. Meinders, B.L.; Hurburg Jr., C.R. Properties of corn screenings. Transactions of the ASAE, 36: 811-819, 1993.

12. Sabino, M.; Prado, G.; Inomata, E.I.; Pedroso, M.O.; Garcia, R.V. Ocorrência natural de aflatoxinas e zearalenona em milho no Brasil - II Parte. Encontro Nacional de Micotoxinas, São Paulo, 1988, p. 21

13. Scussel, V.M. Estudo da incidência de aflatoxina em amendoim (Arachis hypogaea L.), milho (Zea mays L.) e produtos derivados. Campinas, 1984, 138p. (Master's Degree dissertation. Faculdade de Engenharia de Alimentos e Agrícola. UNICAMP).

14. Scott, P.M. Natural Poisons. In: Helrich, K. In: Association of the Official Analytical Chemists. Official Methods of Analysis, 15. Ed. Arlington, 1990. Cap. 49, p.1184-213.
15. Shotwell, O.L.; Goulden, M.L.; Hesseltine, C.W. Aflatoxin contamination: association with foreign material and characteristic fluorescence in damaged corn kernels. Cereal Chem., 49: 458-465, 1972.

16. Shotwell, O.L.; Goulden, M.L.; Hesseltine, C.W. Aflatoxin: distribution in contaminated corn. Cereal Chem., 51: 492-9, 1974.

17. Soares, L.M.V.; Rodriguez-Amaya, D.B. Survey of aflatoxins, ochratoxin A, zearalenone and sterigmatocystin in some Brazilian food by using multitoxin thin-layer chromatographic method. $J$. Assoc. Off. Anal. Chem., 72: 22-26, 1989.

18. Sylos, C.M.; Rodriguez-Amaya, D.B.; Santurio, J.M.; Baldissera, M.A. Occurrence of aflatoxins and cyclopiazonic acid in Brazilian peanut and corn. International IUPAC Symposium on Mycotoxins and Phycotoxins, Rome, 1996, p.132.

19. Watson, S.A. Measurement and maintenance of quality. In: Corn: Chemistry and Technology, $1^{\text {st }}$ ed. American Association of Cereal Chemists, Saint Paul, 1987, cap. 5, p.125-184.

20. Whitaker, T.B.; Dickens, J.W.; Monroe, R.J. Variability associated with testing corn for aflatoxin. J. Assoc. Off. Anal. Chem., 56: 789794, 1979 . 